\title{
MIGRATIONS OF UKRAINIAN POPULATION TO POLAND AT THE TURN OF THE 20TH AND 21ST CENTURIES - SITUATION, REASONS, CHALLENGES
}

\author{
Małgorzata Białas, Adrian Solek
}

\begin{abstract}
The aim of this paper is to present the migration processes of the Ukrainian population to Poland at the turn of 20th and 21st centuries, including their directions, intensity and causes. The paper shows also legal acts regulating these issues and as well as their amendments introduced after Poland's access to the Schengen zone, that might have influence on the size of the migration streams and indirectly on the domestic labour market. The assessment of Poland's migration policy according to the needs of the economy and an attempt to outline desired trends in this area will also be made.
\end{abstract}

Keywords: labour market, migration policy, Schengen zone, Ukrainian-Polish relationship. 